that what is important is not racial and sexual differences per se but the difference those differences make. They place the focus of attention where it should be-on political processes and institutions, not groups of women and African Americans. Finally, they open up the curriculum in new ways. They enable me to include more material about women and Blacks in my courses (important for its own sake), but to do so as a vehicle for exploring political processes and institutions from a fresh perspective.

Admittedly, there is not yet a great deal of material available (especially on the undergraduate level) that facilitates the inclusion of race and gender in these ways. Articles and books by historians and historically oriented political scientists have worked best because their attention to change over time helps to emphasize that the meaning, place, and political significance of race and gender are socially constructed, highly fluid, and historically variable (not static attributes of skin color or reproductive organs).

\section{References}

MacKinnon, Catherine. 1987. Feminism Unmodified. Cambridge, MA: Harvard University Press.
Skocpol, Theda. 1991. Protecting Soldiers and Mothers. Cambridge, MA: Harvard University Press.

Weir, Margaret. 1992. Jobs and Politics. Princeton, NJ: Princeton University Press.

Woodward, C. Vann. 1955 (or any later edition). The Strange Career of Jim Crow. New York: Oxford University Press.

\section{About the Author \\ Helene Silverberg was assistant professor of politics at Princeton University at the time of her panel presentation. She is currently assistant professor of political science at the University of California, Santa Barbara.}

\title{
Social Hierarchies as Systems of Power
}

\section{Spike Peterson, University of Arizona}

My starting point, both inside and outside the classroom, is the assumption that social hierarchies such as race, physical ability, gender, class, age, and sexual preference constitute interlocking systems of power. Because these systems are empirically as well as conceptually linked, understanding any particular oppression requires analysis and action that takes seriously the connections among systems of power-even though these are not always complementary and sometimes contradict each other. Ability to see the connections depends on developing historical and cross-disciplinary contextual frameworks. The objective is to understand how we make (not dis-cover) our world(s) and how to remake (not reify) them in the light of critiques of domination.

In class, to show patterns of similarity and difference in domination practices, I list a number of "isms" across the chalkboard: anti-Semitism, racism, ageism, heterosexism, ableism, sexism, classism. I then ask students to identify the characteristic features of each system of domination. How is each subordinated group depicted in imagery, humor, stereotypes, linguistic and literary conventions, religious teachings, and by the press and on television? How do direct and indirect forms of power shape the group's experience spatially (e.g., residential segregation or restriction to the private sphere); temporally (e.g., historical variation in the group's oppression and different effects at different points in the life cycle); economically (e.g., discrimination in education, training, and employment, and unequal access to decision-making power and material resources); politically (e.g., unequal rights and exclusion from elite decision-making and formal political power); through violence or the threat of violence (e.g., police brutality, rape, battering, mugging, lynching, genocide)?

Patterns of similarity include how stereotypes, media depictions, and religious dogma reproduce negative stereotypes and "blaming the victim"; how apparently "harmless" jokes naturalize and trivialize domination by casting subordinated groups as inferior or suspiciously feminine; how economic impoverishment reproduces cycles of oppression; how forms of direct and structural violence back up all systems of unequal power.

Differences include the dismissal of the elderly and disabled as unproductive members of society; the exclusion of women and minorities from prestigious job categories and positions of intellectual, religious, and political authority; the issues of "passing" including discrimination against gays/lesbians only if they are "out"; differences in the use and threat of violence including rape and battering of women that is personal-by those they know/ love-but also impersonal-in public and as a component of militarism and commercialized sex; enslavement and lynching of Blacks in the past, and police brutality in the present; state-based genocidal elimination of Jews and indigenous peoples; and the presence of both targeted and impersonal gay bashing and murder.

Societal consciousness of and responses to oppression also reveal patterns. Most people consider racism more oppressive than sexism, in part because we deny the systemic violence that women suffer, and we are relatively more conscious of the economic immisera- 
tion and brutality suffered by people of color. Heterosexism remains largely invisible because we take gender hierarchy and its rigid dichotomy of masculine versus feminine for granted. Gay/lesbian oppression is also trivialized when people believe sexual orientation is a matter of choice: homosexuals "don't have to be that way" and therefore "deserve what they get." The virulence of anti-Semitism is discounted by stereotyping Jews as well off. Ageism is the best example of our irrationality: we are all subject to aging but we reproduce this system of domination in countless ways. Finally, structural violence is rendered invisible by mainstream critiques that focus only on direct violence, leaving in place the degradations wrought by instrumental reason, economic injustice, masculinism, and exclusionary politics.

Exploring patterns of power in- variably raises the inter-related and definitively political questions of how to assign responsibility and identify transformational strategies. Blaming contemporary individuals for historical systems of domination invites defensive and unconstructive responses. Yet all systems of power are ultimately reproduced or transformed by individuals acting in concert. Members of privileged groups have more power to change the status quo and more responsibility for doing so because they in fact benefit from systemic hierarchies whether or not they intend to: men who do not rape still benefit from patriarchy, and White women who promote feminism still benefit from racism. Because we are all implicated in systems of power, neutrality is not an option: whatever we do or don't do has effects. We must present this recognition not as paralyzing but politicizing. We are empowered to do so by examining the connections among systems of power, thereby enriching our knowledge of politics and enabling more effective transformational strategies.

\section{References}

hooks, bell. 1984. Feminist Theory: From Margin to Center. Boston: South End.

Peterson, V. Spike. 1992. "Transgressing Boundaries." Millennium: Journal of International Studies 21:2, 183-206.

Peterson, V. Spike, and Anne Sisson Runyan. 1993. Global Gender Issues. Boulder, CO: Westview.

Young, Iris Marion. 1990. Justice and the Politics of Difference. Princeton, NJ: Princeton University Press.

\section{About the Author}

V. Spike Peterson is assistant professor of political science at the University of Arizona.

\section{The Case of African American Women and Politics}

\section{Jewel Limar Prestage, Banneker Honors College, Prairie View A\&M University}

The effort to mainstream gender and race in political science courses over the past three decades has met with varying degrees of success depending on the nature of the courses, who teaches the courses, and the availability of relevant information, published and unpublished. The observations that follow are offered on the basis of my experiences with initiatives directed toward mainstreaming "race" and "gender," separately and collectively, for nearly four decades. During my tenure in the profession, my teaching responsibilities have included the introductory American Government courses and other traditional listings such as Political Parties, Comparative Government, and The Presidency as well as, more recently, Women in Politics, Black Politics, Public Policy, Introduction to Political Science, Political Socialization, and honors colloquia. On rare occa- sions, special topics seminars permit the maximum flexibility in choice of topics and emphasis.

One major problem, which became obvious early, is that the experiences of women and racial minorities did not fit easily into the major frames of reference or organizational schemes of the standard textbooks used in American Government courses. Marked by emphasis on voting and officeholding, Supreme Court decisions, and political parties, these textbooks left women and minorities out of the political mainstream as activists. Inclusion of information on gender and race required not only supplementing the textbook information, but reinterpreting essential concepts and offering new frames of reference, sometimes diametrically opposed to that of the textbook.

It was necessary to establish "women" as a special category when "race" was the focus and "race" as a relevant category in the focus on "women." Ensuring that students read materials on both race and gender was accomplished by a list of "required" readings. However, there was very little available information or research by political scientists on either race or women in the 1960 s and early 1970 s. Thus, the creation of an information base was a major agenda item, even as courses on Black Politics and Women in Politics were added to the curricula.

In the case of information about African American women, most of what was available did not come from political scientists, but rather from publications such as those by an African American women's sorority, an African American journalist, and popular magazines directed to African American readers. This dearth of information might be traced to two factors: the limited participation of women and 